Article

\title{
Limits to the Biofortification of Leafy Brassicas with Zinc
}

\author{
Philip J. White ${ }^{1,2, *}$, Paula Pongrac ${ }^{1,+}+\mathbb{D}$, Claire C. Sneddon ${ }^{1, \ddagger}$, Jacqueline A. Thompson ${ }^{1}$ and \\ Gladys Wright ${ }^{1}$ \\ 1 Ecological Science Group, The James Hutton Institute, Invergowrie, Dundee DD2 5DA, UK; \\ paula.pongrac@gmail.com (P.P.); c.c.sneddon@dundee.ac.uk (C.C.S.); \\ jacqueline.thompson@hutton.ac.uk (J.A.T.); gladys.wright@hutton.ac.uk (G.W.) \\ 2 Distinguished Scientist Fellowship Program, King Saud University, Riyadh 11451, Saudi Arabia \\ * Correspondence: philip.white@hutton.ac.uk; Tel.: +44-1382-560043 \\ + Current Address: Biotechnical Faculty, University of Ljubljana, SI-1000 Ljubljana, Slovenia. \\ $\ddagger$ Current Address: Medical Research Institute, Ninewells Hospital and Medical School, University of Dundee, \\ Dundee DD1 9SY, UK.
}

Received: 24 January 2018; Accepted: 22 February 2018; Published: 27 February 2018

\begin{abstract}
Many humans lack sufficient zinc $(\mathrm{Zn})$ in their diet for their wellbeing and increasing $\mathrm{Zn}$ concentrations in edible produce (biofortification) can mitigate this. Recent efforts have focused on biofortifying staple crops. However, greater $\mathrm{Zn}$ concentrations can be achieved in leafy vegetables than in fruits, seeds, or tubers. Brassicas, such as cabbage and broccoli, are widely consumed and might provide an additional means to increase dietary $\mathrm{Zn}$ intake. Zinc concentrations in brassicas are limited primarily by $Z n$ phytotoxicity. To assess the limits of $Z n$ biofortification of brassicas, the Zn concentration in a peat:sand $(v / v 75: 25)$ medium was manipulated to examine the relationship between shoot $\mathrm{Zn}$ concentration and shoot dry weight (DW) and thereby determine the critical shoot $\mathrm{Zn}$ concentrations, defined as the shoot $\mathrm{Zn}$ concentration at which yield is reduced below $90 \%$. The critical shoot $\mathrm{Zn}$ concentration was regarded as the commercial limit to $\mathrm{Zn}$ biofortification. Experiments were undertaken over six successive years. A linear relationship between $\mathrm{Zn}$ fertiliser application and shoot $\mathrm{Zn}$ concentration was observed at low application rates. Critical shoot $\mathrm{Zn}$ concentrations ranged from 0.074 to $1.201 \mathrm{mg} \mathrm{Zn} \mathrm{g}^{-1} \mathrm{DW}$ among cabbage genotypes studied in 2014, and between 0.117 and $1.666 \mathrm{mg} \mathrm{Zn} \mathrm{g}^{-1} \mathrm{DW}$ among broccoli genotypes studied in 2015-2017. It is concluded that if $5 \%$ of the dietary $\mathrm{Zn}$ intake of a population is currently delivered through brassicas, then the biofortification of brassicas from 0.057 to $>0.100 \mathrm{mg} \mathrm{Zn} \mathrm{g}^{-1} \mathrm{DW}$ through the application of $\mathrm{Zn}$ fertilisers could increase dietary Zn intake substantially.
\end{abstract}

Keywords: biofortification; Brassica oleracea L.; broccoli; cabbage; nutrition; toxicity; zinc

\section{Introduction}

It is estimated that over one-fifth of the world's population suffers from zinc $(\mathrm{Zn})$ deficiency, which results in impaired development, ill health, and a reduction in gross domestic product [1-5]. One strategy to increase human dietary $\mathrm{Zn}$ intake is to increase $\mathrm{Zn}$ concentrations in edible produce. This strategy is termed biofortification and can be achieved through the use of $\mathrm{Zn}$ fertilisers on plant genotypes that have greater ability to acquire and accumulate $\mathrm{Zn}$ in their edible tissues [1,4-9]. Zinc might be applied to the soil as inorganic or organic fertilisers or to foliage as soluble salts [1,7,9-11]. Inorganic fertilisers are often preferred because of their consistent composition; foliar applications are most effective where the phytoavailability of Zn decreases rapidly when applied to the soil [1,5]. Recent biofortification efforts have focused largely on developing germplasm and agronomic strategies to increase $\mathrm{Zn}$ concentrations in staple crops including cereals, pulses, cassava and potatoes, and $\mathrm{Zn}$ 
concentrations approaching $0.02-0.10 \mathrm{mg} \mathrm{g}^{-1}$ dry weight (DW), depending upon the crop, have been achieved $[1,6,9,12-21]$. However, greater $\mathrm{Zn}$ concentrations can be achieved in leafy vegetables than in fruits, seeds or tubers because $\mathrm{Zn}$ transport in the phloem limits $\mathrm{Zn}$ accumulation in the latter tissues [13]. Zinc concentrations in leafy vegetables appear to be limited primarily by $\mathrm{Zn}$ phytotoxicity, suggesting that concentrations of $0.10-0.70 \mathrm{mg} \mathrm{Zn} \mathrm{g}^{-1} \mathrm{DW}$ shoot might be achieved without loss of yield [13]. Thus, $\mathrm{Zn}$ biofortification of leafy vegetables might also provide a means to increase $\mathrm{Zn}$ intake by human populations.

Leafy vegetables are a significant source of micronutrients for human populations, especially those with low incomes or with a vegetarian diet [3,4]. Brassicaceous vegetables, such as cabbage (Brassica oleracea var. capitata) and broccoli (B. oleracea L. var. italica), are among the most commonly consumed and economically important vegetables in the world [22,23]. The health benefits of brassicaceous vegetables are not only associated with their mineral composition but also their vitamin content and the presence of other organic compounds, particularly glucosinolates [22,24,25]. Although leafy vegetables currently contribute proportionally less $\mathrm{Zn}$ to human diets than animal products or cereals [3,4], their greater potential for Zn biofortification could be exploited to increase $\mathrm{Zn}$ intake and improve human health.

A large variation in shoot $\mathrm{Zn}$ concentration has been reported among the genotypes of B. oleracea [26-32]. For example, shoot $\mathrm{Zn}$ concentration among 36 cabbage genotypes grown together in a field in Himachal Pradesh, India, ranged from 0.002 to $0.005 \mathrm{mg} \mathrm{Zn} \mathrm{g}^{-1}$ fresh weight [29]; significant differences in leaf $\mathrm{Zn}$ concentrations were observed among three cabbage genotypes grown together in the field in Pennsylvania, USA [26]; floret $\mathrm{Zn}$ concentrations of 10 broccoli genotypes grown together in Poznań, Poland, ranged from 0.042 to $0.066 \mathrm{mg} \mathrm{Zn} \mathrm{g}^{-1} \mathrm{DW}$ [30]; the average shoot $\mathrm{Zn}$ concentration of 22 kale (B. oleracea var. acephala) genotypes grown together in the field in New Hampshire, USA, over two years ranged from 0.033 to $0.060 \mathrm{mg} \mathrm{Zn} \mathrm{g}^{-1} \mathrm{DW}$ [27]; and leaf Zn concentrations of 6 kale genotypes grown in the field in KwaZulu-Natal Province, South Africa, ranged from 0.025 to $0.032 \mathrm{mg} \mathrm{Zn} \mathrm{g}^{-1}$ DW [33]. However, although the heritability of shoot $\mathrm{Zn}$ concentration in B. oleracea is significant and several chromosomal quantitative trait loci (QTL) affecting shoot $\mathrm{Zn}$ concentration have been identified in this species, the heritability is often low and the QTL identified depends on the growth conditions [28,29,34]. The aim of the experiments reported here was, therefore, to determine the limit to $\mathrm{Zn}$ biofortification - using a $\mathrm{Zn}$ fertiliser - of two leafy brassicas, cabbage and broccoli, which contribute significantly to human diets worldwide. The $\mathrm{Zn}$ concentration in a peat:sand $(v / v 75: 25)$ potting medium was manipulated using zinc nitrate in order to examine the relationship between shoot $\mathrm{Zn}$ concentration and shoot dry biomass. This was to determine the critical shoot $\mathrm{Zn}$ concentration-defined as the shoot $\mathrm{Zn}$ concentration at which the yield was reduced below $90 \%$ [35] —of different genotypes. This value was regarded as the commercial limit to $\mathrm{Zn}$ biofortification. The manipulation of shoot $\mathrm{Zn}$ concentration through $\mathrm{Zn}$ applications to the substrate was necessary because the $\mathrm{Zn}$ concentrations of shoot tissues are difficult to determine unambiguously following the application of foliar $\mathrm{Zn}$ fertilisers. The $\mathrm{Zn}$ concentration in the substrate was manipulated using an inorganic $\mathrm{Zn}$ fertiliser rather than an organic amendment to avoid any potential effects of other components of organic amendments.

\section{Materials and Methods}

\subsection{Plant Material}

Five cabbage (Brassica oleracea L. var. capitata) genotypes were selected for study on the basis of their potentially large leaf zinc $(\mathrm{Zn})$ concentrations based on data presented by [28]. The genotypes Bison, Cape Horn and Red Drumhead were grown in 2012, 2013 and 2014. The genotype Elisa was grown only in 2012. The genotype Tundra was grown only in 2013 and 2014. Seeds of Bison, Cape Horn, Red Drumhead and Tundra were obtained from Kings Seeds (Colchester, UK) and seeds of Elisa were obtained from Thompson \& Morgan (Ipswich, UK). Four broccoli (Brassica oleracea L. var. italica) genotypes, Belstar, Chevalier, Marathon and Waltham 29, were studied in 2015, 2016 and 2017. 
These genotypes were selected on the basis of their potentially contrasting leaf $\mathrm{Zn}$ concentrations based on data presented by [28]. Seeds of Belstar, Chevalier, Marathon and Waltham 29 were obtained from Van Meuwen (Spalding, UK), Kings Seeds Direct (Colchester, UK) and Unwins (Huntingdon, UK).

\subsection{Growth Conditions}

Seeds of cabbage were germinated in square Petri dishes (length $\times$ width $\times$ depth $=100 \mathrm{~mm} \times$ $100 \mathrm{~mm} \times 18 \mathrm{~mm}$; Camlab, Cambridge, UK) on blue germination paper (Anchor Paper Company, St Paul, MN, USA) moistened with $10 \mathrm{~mL}$ deionised water. One week after placing the seeds in the Petri dishes, three to ten germinated seedlings of a genotype were transplanted to each pot containing 1 litre of the potting medium described in the next paragraph. Seedlings were thinned to a density of one seedling per pot two weeks after transplanting and grown for a further four weeks before harvesting. Ten seeds of broccoli were sown directly into pots containing 1 litre of potting medium. Broccoli seedlings were thinned to a density of one seedling per pot three weeks after sowing and grown for a further six weeks before harvesting. Thus, cabbage was harvested six weeks after transplanting pre-germinated seedlings to pots and broccoli was harvested nine weeks after sowing seeds into pots. Both cabbage and broccoli plants were at the true leaf/rosette stage of development, immediately prior to heading.

Plants were grown in an unheated glasshouse at The James Hutton Institute, Dundee, UK (latitude $56.4566^{\circ} \mathrm{N}$, longitude $3.0708^{\circ} \mathrm{W}$ ) in a potting medium, henceforth described as a "substrate", with $\mathrm{Zn}$ concentrations ranging from sufficient to phytotoxic. The standard substrate was made in bulk each year and comprised 75\% peat (Sinclairs Professional Peat, Sinclair Pro, Ellesmere Port, UK) and 25\% sand mixed with $0.225 \mathrm{~g} \mathrm{~L}^{-1}$ single superphosphate, $0.4 \mathrm{~g} \mathrm{~L}^{-1}$ ammonium nitrate, $0.75 \mathrm{~g} \mathrm{~L}^{-1}$ potassium nitrate, $2.25 \mathrm{~g} \mathrm{~L}^{-1}$ ground limestone, $2.25 \mathrm{~g} \mathrm{~L}^{-1}$ Magnesian limestone and $0.51 \mathrm{~g} \mathrm{~L}^{-1}$ of a trace element mixture containing $0.16 \%$ boron, $0.79 \%$ copper, $11.82 \%$ iron, $1.97 \%$ manganese, and $0.04 \%$ molybdenum by weight. The density of the substrate was $625 \mathrm{~g} \mathrm{~L}^{-1}$ when dry and $822 \mathrm{~g} \mathrm{~L}^{-1}$ when watered to holding capacity. The standard substrate contained $9.4 \mathrm{mg} \mathrm{Zn} \mathrm{L}^{-1}$ and $<0.1 \mathrm{mg} \mathrm{L}^{-1}$ water-extractable $\mathrm{Zn}(n=6)$ prior to any further additions.

The standard substrate was thoroughly mixed and sieved before zinc nitrate was added to achieve the specified $\mathrm{Zn}$ concentrations. Zinc nitrate was employed rather than zinc sulphate to avoid any potential effect of increasing sulphate bioavailability on $\mathrm{Zn}$ accumulation. Six treatments were established in all experiments. In 2012, the treatments were the additions of $0,0.075,0.15,1.5,150$ or $3000 \mathrm{mg} \mathrm{Zn} \mathrm{L}^{-1}$ substrate. In 2013, the treatments were the additions of $0,0.15,150,500,1000$ or $1500 \mathrm{mg} \mathrm{Zn} \mathrm{L}^{-1}$ substrate. In 2014, 2015, 2016 and 2017 the treatments were the additions of 0, 1.5, $15,150,300$ or $450 \mathrm{mg} \mathrm{Zn} \mathrm{L}^{-1}$ substrate. The substrate was watered to holding capacity immediately before the experiments. When watered to holding capacity the $\mathrm{pH}$ of the solution in the substrate was ca. 6.8. Three replicate pots of each genotype $x$ treatment were established in 2012 and 2013. Ten replicate pots of each genotype $x$ treatment were established in 2014, 2015, 2016 and 2017. Pots were arranged in a blocked design with one replicate of each genotype $x$ treatment combination in a random location within each block.

Surviving plants were harvested on 12 September 2012, 27 June 2013, 22 July 2014, 29 July 2015, 5 October 2016 and 25 July 2017. The accumulated temperature $x$ time during plant growth in the glasshouse was $606.7^{\circ} \mathrm{C}$ day in $2012,525.3^{\circ} \mathrm{C}$ day in $2013,638.7^{\circ} \mathrm{C}$ day in $2014,820.1^{\circ} \mathrm{C}$ day in 2015 , $929.4^{\circ} \mathrm{C}$ day in 2016 and $908.9^{\circ} \mathrm{C}$ day in 2017. The accumulated solar radiation in the glasshouse during plant growth was $524.0 \mathrm{MJ} \mathrm{m}^{-2}$ in $2012,702.5 \mathrm{MJ} \mathrm{m}^{-2}$ in $2013,716.3 \mathrm{MJ} \mathrm{m}^{-2}$ in $2014,1046.4 \mathrm{MJ} \mathrm{m}^{-2}$ in 2015, 702.4 $\mathrm{MJ} \mathrm{m}^{-2}$ in 2016 and $1011.7 \mathrm{MJ} \mathrm{m}^{-2}$ in 2017.

\subsection{Plant Analysis}

Shoot fresh weight (FW) was determined at harvest and shoot dry weight (DW) was determined following drying to a constant weight in an oven at $70{ }^{\circ} \mathrm{C}$. Zinc concentrations were determined following acid digestion of dried shoot material using inductively coupled plasma mass spectrometry (ICP-MS) as described by White et al. [36]. Accurately weighed subsamples (c. $50 \mathrm{mg}$ DW) were 
digested in closed vessels using a microwave digester (MARS Xpress, CEM Microwave Technology, Buckingham, UK). Samples were first digested with $10 \mathrm{~mL}$ concentrated nitric acid $\left(\mathrm{HNO}_{3}\right)$ before $3 \mathrm{~mL}$ of $30 \%$ hydrogen peroxide $\left(\mathrm{H}_{2} \mathrm{O}_{2}\right)$ was added to each vessel and digestion completed. Digested samples were diluted with milliQ (sterile, $18.2 \mathrm{M} \Omega \mathrm{cm}$ ) water before $\mathrm{Zn}$ concentrations were determined using ICP-MS (PerkinElmer ELAN, DRCe, Monza, Italy). Blank digestions were performed to determine background Zn concentrations and a tomato leaf standard (Reference 1573a; National Institute of Standards and Technology, NIST, Gaithersburg, MD, USA) was used as an analytical control.

\subsection{Statistics}

Data are expressed as the mean \pm standard error of the mean (SE) for $n$ observations. The relationships between shoot biomass $(\mathrm{W})$ and the zinc concentration $(\mathrm{Zn})$ in the substrate or shoot tissue were fitted to a sigmoidal function: $\mathrm{W}=\mathrm{a} /\left(1+\operatorname{EXP}\left(\mathrm{b}^{*}((\mathrm{Zn})-\mathrm{c})\right)\right)+\mathrm{d}$, where the minimum biomass equals $\mathrm{d}$, the maximum biomass equals $\mathrm{a}+\mathrm{d}, \mathrm{c}$ is the $(\mathrm{Zn})$ at the point of inflection and the slope of the relationship at the point of inflection is given by $-a b / 4$.

\section{Results}

The relationships between substrate fertiliser $\mathrm{Zn}$ concentration, which is less than the actual substrate Zn concentration but is henceforth termed 'substrate Zn concentration' for brevity, and shoot fresh weight (FW), shoot dry weight (DW) and shoot $\mathrm{Zn}$ concentration of cabbage seedlings were studied in experiments performed in 2012, 2013 and 2014 (Table S1). The experiments performed in 2012 and 2013 narrowed the range of substrate $\mathrm{Zn}$ concentrations required to determine the 'critical' substrate and shoot Zn concentrations at which shoot DW was 90\% of its maximal value [13]. The experiment performed in 2012 indicated that neither shoot FW nor shoot DW of cabbage genotypes was greatly reduced at substrate concentrations up to $150 \mathrm{mg} \mathrm{L}^{-1}$ and that shoot $\mathrm{Zn}$ concentration increased as the substrate $\mathrm{Zn}$ concentration was increased (Table S1). The genotype Elisa did not grow well in the substrate employed in these experiments and was replaced by Tundra in subsequent experiments. The experiment performed in 2013 indicated that the sensitivity of shoot FW and shoot DW to increasing substrate Zn concentration followed the sequence Red Drumhead $>$ Bison $>$ Cape Horn > Tundra (Table S1). The critical substrate Zn concentration at which shoot DW was $90 \%$ of its maximal value was $<0.15 \mathrm{mg} \mathrm{L}^{-1}$ for Red Drumhead, between 0.15 and $150 \mathrm{mg} \mathrm{L}^{-1}$ for Bison and between 150 and $500 \mathrm{mg} \mathrm{L}^{-1}$ for Cape Horn and Tundra. Shoot $\mathrm{Zn}$ concentration increased linearly with increasing substrate $\mathrm{Zn}$ concentration with gradients between 7.2 and $13.6 \mathrm{mg} \mathrm{Zn} \mathrm{kg}{ }^{-1} \mathrm{DW} /$ $\mathrm{mg} \mathrm{Zn} \mathrm{L}^{-1}$ (Bison = 9.9, Cape Horn = 8.4, Red Drumhead = 13.6, Tundra = 7.2). The critical shoot $\mathrm{Zn}$ concentrations were $<0.18 \mathrm{mg} \mathrm{g}^{-1} \mathrm{DW}$ for Red Drumhead, between 0.05 and $1.65 \mathrm{mg} \mathrm{g}^{-1} \mathrm{DW}$ for Bison, between 1.36 and $4.27 \mathrm{mg} \mathrm{g}^{-1} \mathrm{DW}$ for Cape Horn and between 1.05 and $3.73 \mathrm{mg} \mathrm{g}^{-1} \mathrm{DW}$ for Tundra. Experiments in both 2012 and 2013 indicated considerable variation in the responses of individual plants of all genotypes grown under identical conditions to substrate $\mathrm{Zn}$ concentration, and that a large number of replicates would be required to obtain a more precise estimate of the critical substrate and shoot $\mathrm{Zn}$ concentrations for shoot DW accumulation.

In the experiments performed on cabbage in 2014, increasing substrate $\mathrm{Zn}$ concentration above about $100-150 \mathrm{mg} \mathrm{L}^{-1}$ reduced shoot DW of all cabbage genotypes studied (Figure 1A-D). However, estimates of critical substrate $\mathrm{Zn}$ concentrations were relatively imprecise. For Bison, the relationship between substrate $\mathrm{Zn}$ concentration and shoot DW could be fitted with a sigmoidal function, indicating a critical substrate $\mathrm{Zn}$ concentration of $96 \mathrm{mg}$ fertiliser $\mathrm{Zn} \mathrm{g}^{-1} \mathrm{DW}$ substrate (Figure 1A, Table 1). Shoot DW of the Cape Horn genotype increased greatly with the addition of $0.15 \mathrm{mg} \mathrm{L}^{-1} \mathrm{Zn}$ to the substrate, suggesting that the $\mathrm{Zn}$ in the substrate itself was insufficient to support maximal growth of this genotype in this experiment. The relationship between substrate $\mathrm{Zn}$ concentration above $0.15 \mathrm{mg} \mathrm{L}^{-1}$ and shoot DW could, however, be fitted by a sigmoidal function indicating a critical substrate $\mathrm{Zn}$ concentration of $100 \mathrm{mg} \mathrm{L}^{-1}$ (Figure 1B, Table 1). The relationship between substrate $\mathrm{Zn}$ concentration and shoot DW for Red Drumhead could not be fitted by a sigmoidal function but 
indicated a critical substrate $\mathrm{Zn}$ concentration of $5 \mathrm{mg} \mathrm{L}^{-1}$ (Figure 1C, Table 1). The genotype Tundra was relatively insensitive to the addition of $<450 \mathrm{mg} \mathrm{Zn} \mathrm{L}^{-1}$ and was estimated to have a critical substrate $\mathrm{Zn}$ concentration of $260 \mathrm{mg} \mathrm{L}^{-1}$ (Figure 1D, Table 1). The ranking of genotypes and estimates of critical values were generally consistent with data obtained in 2013.

Increasing the substrate $\mathrm{Zn}$ concentration increased shoot $\mathrm{Zn}$ concentration in all cabbage genotypes (Figure 1E-H). The relationship between substrate $\mathrm{Zn}$ concentration and shoot $\mathrm{Zn}$ concentration was linear in the genotypes Bison and Tundra, with a gradient of 5.80 and $4.62 \mathrm{~L} \mathrm{~kg}^{-1} \mathrm{DW}$, respectively, but asymptotic in Cape Horn and Red Drumhead, reaching a maximum of 1.70 and $1.91 \mathrm{mg} \mathrm{Zn} \mathrm{g}^{-1} \mathrm{DW}$, respectively (Figure 1I-L, Table 2). From the experiments performed in 2014, the critical shoot Zn concentrations of Bison, Cape Horn, Red Drumhead and Tundra were estimated to be 0.79, 0.80, 0.074 and $1.20 \mathrm{mg} \mathrm{Zn} \mathrm{g}^{-1} \mathrm{DW}$, respectively (Figure 1I-L, Table 1). The ranking of genotypes and the estimates of critical values were generally consistent with data obtained in 2013.
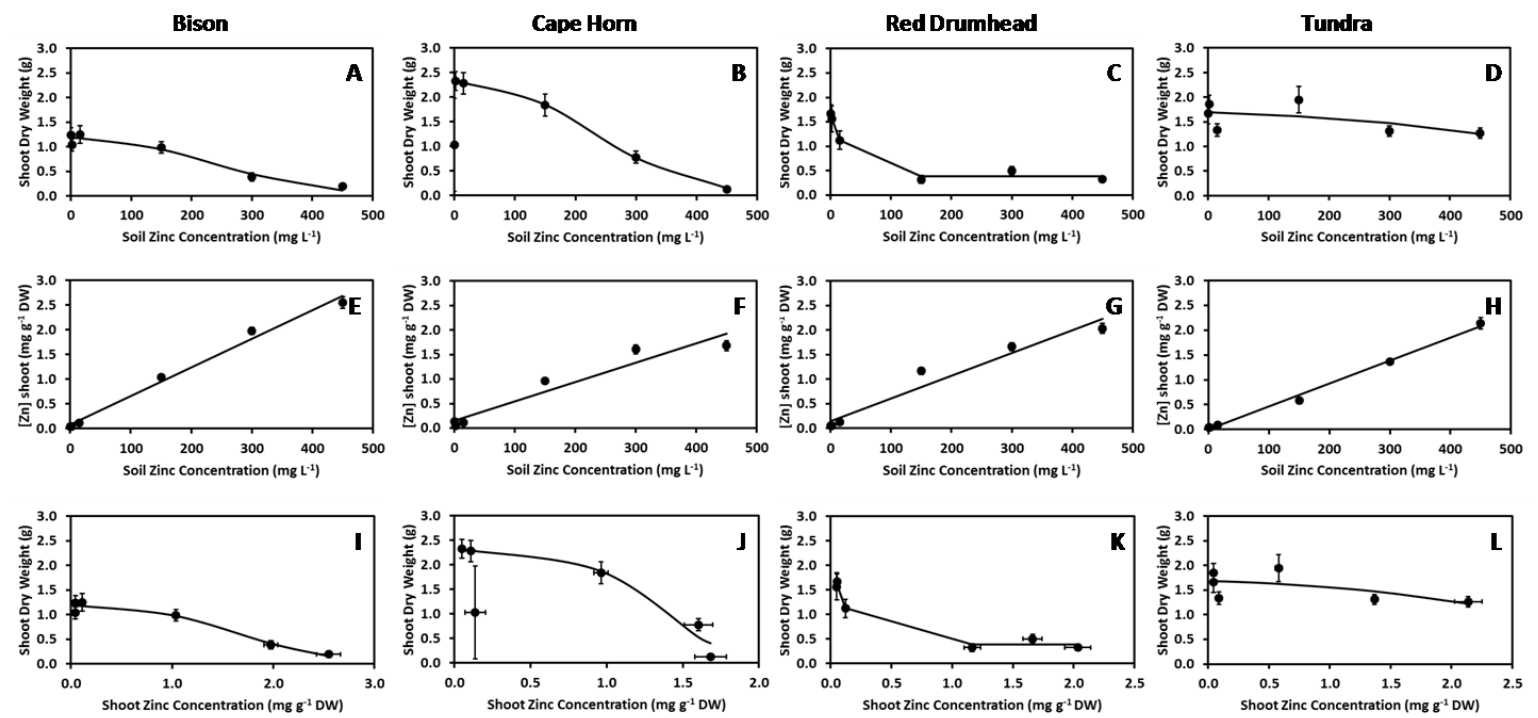

Figure 1. Response of cabbage genotypes to the addition of zinc ( $\mathrm{Zn})$ fertiliser to the substrate. Top row: Relationship between the addition of $\mathrm{Zn}$ fertiliser to substrate (substrate $\mathrm{Zn}$ concentration, ( $\mathrm{Zn})$ ) and shoot dry weight (DW) of (A) Bison, (B) Cape Horn, (C) Red Drumhead and (D) Tundra genotypes grown in 2014. Middle row: Relationship between substrate Zn concentration and shoot Zn concentration of (E) Bison, (F) Cape Horn, (G) Red Drumhead and (H) Tundra genotypes grown in 2014. Parameters for linear regression lines are given in Table 2. Bottom row: Relationship between shoot $\mathrm{Zn}$ concentration $((\mathrm{Zn}))$ and shoot dry weight of (I) Bison, (J) Cape Horn, (K) Red Drumhead and (L) Tundra genotypes. Regression lines are fitted to the equation $\mathrm{DW}=\mathrm{a} /\left(1+\operatorname{EXP}\left(b^{*}((\mathrm{Zn})-\mathrm{c})\right)\right)+\mathrm{d}$, where the minimum biomass equals $d$, the maximum biomass equals $a+d, c$ is the substrate $(\mathbf{A}-\mathbf{D})$ or shoot $(\mathbf{I}-\mathbf{L}) \mathrm{Zn}$ concentration at the point of inflection and the slope of the relationship at the point of inflection is given by $-\mathrm{ab} / 4$. For all lines $\mathrm{d}=0$ and $\mathrm{a}$ is the maximum shoot biomass. Parameters $\mathrm{a}, \mathrm{b}$ and $\mathrm{c}$ were: (A) $\mathrm{a}=1.26, \mathrm{~b}=0.0114, \mathrm{c}=248$ for Bison, (B) $\mathrm{a}=2.41, \mathrm{~b}=0.0130, \mathrm{c}=241$ for Cape Horn, (C) not fitted for Red Drumhead, (D) a = 1.77, b = 0.0049, c = 633 for Tundra, $(\mathbf{I}) \mathrm{a}=1.21, \mathrm{~b}=2.19, \mathrm{c}=1.68$ for Bison, (J) $\mathrm{a}=2.31, \mathrm{~b}=4.18, \mathrm{c}=1.31$ for Cape Horn, $(\mathbf{K})$ not fitted for Red Drumhead, $(\mathbf{L}) \mathrm{a}=1.77, \mathrm{~b}=1.05$, $\mathrm{c}=2.91$ for Tundra. Data are shown as the mean and standard error of the mean (Table S1).

The relationships between substrate $\mathrm{Zn}$ concentration and shoot FW, shoot DW and shoot Zn concentration of broccoli seedlings were studied in experiments performed in 2015, 2016 and 2017 (Table S1; Figures 2-4). In all years there was considerable variation in the responses of individual plants of all genotypes grown under identical conditions to substrate Zn concentration (Table S1) and estimates of critical substrate and shoot $\mathrm{Zn}$ concentrations were relatively imprecise (Figures 2 and 4 ). Shoot DW was reduced by increasing substrate Zn concentration in all years in all genotypes (Figure 2). 
However, the estimated critical substrate Zn concentration for shoot DW differed between years and, apparently, among genotypes (Table 1). The critical substrate Zn concentration was greater in 2017, ranging from 271 to $408 \mathrm{mg} \mathrm{Zn} \mathrm{L}^{-1}$ among genotypes, than in 2016, ranging from 43 to $139 \mathrm{mg} \mathrm{Zn}$ $\mathrm{L}^{-1}$ among genotypes, and 2015, ranging from 107 to $121 \mathrm{mg} \mathrm{Zn} \mathrm{L}^{-1}$ among genotypes (Table 1). In 2015, the critical substrate Zn concentration was similar for all genotypes but in both 2016 and 2017, the shoot DW of Belstar appeared less sensitive to substrate $\mathrm{Zn}$ concentration than the other cultivars, whereas the shoot DW of Waltham 29 was among the most sensitive genotypes to substrate Zn concentration (Table 1).
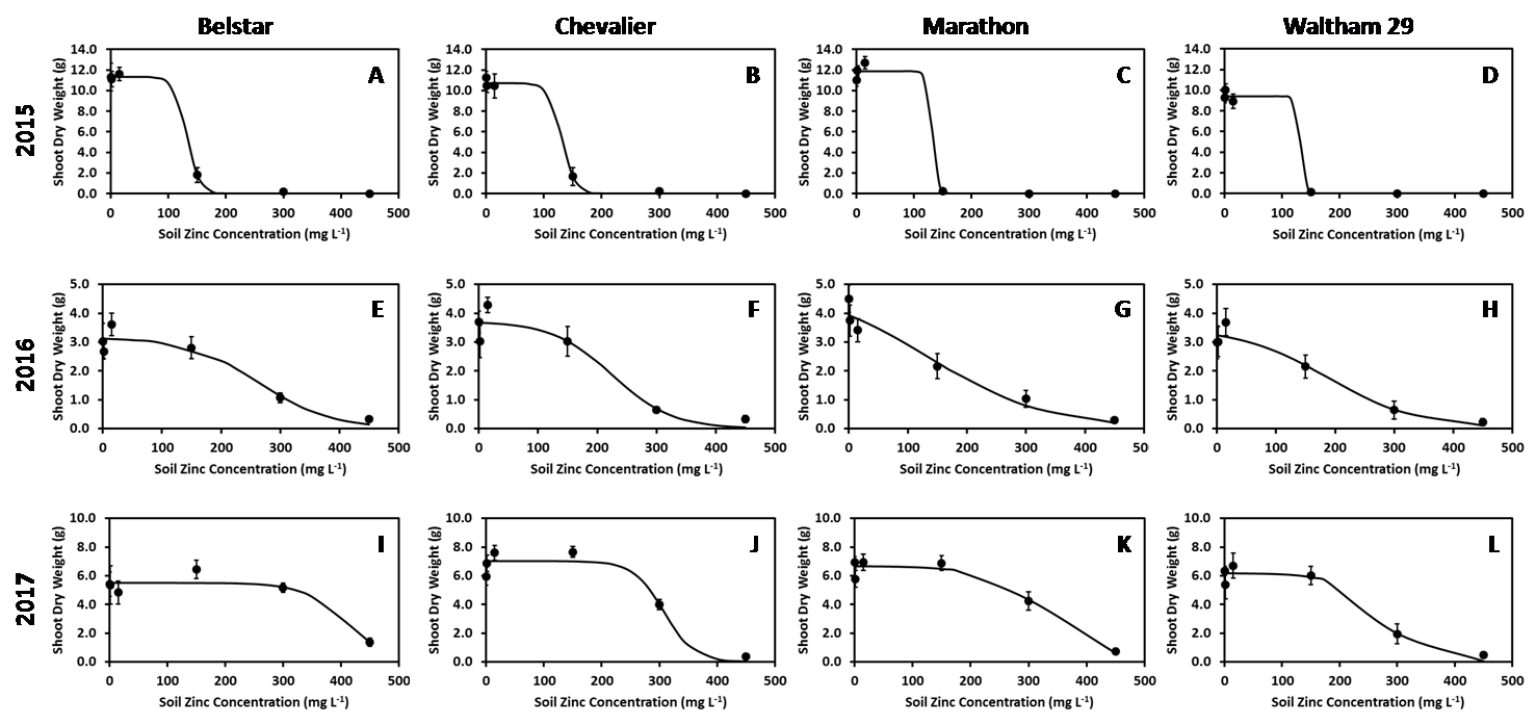

Figure 2. Relationship between substrate zinc concentration $(\mathrm{Zn})$ and shoot dry weight (DW) of (A,E,I) Belstar, (B,F,J) Chevalier, (C,G,K) Marathon and (D,H,L) Waltham 29 broccoli genotypes grown in 2015 (top row), 2016 (middle row) and 2017 (bottom row). Regression lines are fitted to the equation $\mathrm{DW}=\mathrm{a} /\left(1+\operatorname{EXP}\left(\mathrm{b}^{*}((\mathrm{Zn})-\mathrm{c})\right)\right)+\mathrm{d}$, where the minimum biomass equals $\mathrm{d}$, the maximum biomass equals $a+d, c$ is the substrate $Z n$ concentration at the point of inflection and the slope of the relationship at the point of inflection is given by $-a b / 4$. For all lines $d=0$ and $a$ is the maximum shoot biomass. Parameters $\mathrm{a}, \mathrm{b}$ and $\mathrm{c}$ were: $(\mathbf{A}) \mathrm{a}=11.3, \mathrm{~b}=0.0893, \mathrm{c}=131$ for Belstar in 2015, $(\mathbf{B}) \mathrm{a}=10.7, \mathrm{~b}=0.0862$, $c=130$ for Chevalier in 2015, (C) $a=11.9, b=0.2041, c=131$ for Marathon in 2015, (D) $a=9.40, b=0.2181$, $c=131$ for Waltham 29 in 2015, (E) $a=3.16, b=0.0164, c=265$ for Belstar in 2016, (F) a = 3.72, b = 0.0197, $\mathrm{c}=225$ for Chevalier in 2016, $(\mathbf{G}) \mathrm{a}=4.95, \mathrm{~b}=0.01, \mathrm{c}=135$ for Marathon in 2016, $(\mathbf{H}) \mathrm{a}=3.51, \mathrm{~b}=0.0132$, $c=189$ for Waltham 29 in 2016, (I) $a=5.51, b=0.0264, c=408$ for Belstar in 2017, (J) a = 7.03, b = 0.0380, $c=308$ for Chevalier in 2017, $(\mathbf{K}) \mathrm{a}=6.68, \mathrm{~b}=0.0193, \mathrm{c}=332$ for Marathon in 2017, $(\mathbf{L}) \mathrm{a}=6.18, \mathrm{~b}=0.0255$, $c=271$ for Waltham 29 in 2017. Data are shown as the mean and standard error of the mean (Table S1).

Shoot $\mathrm{Zn}$ concentration generally increased linearly with increasing substrate $\mathrm{Zn}$ concentration, although this relationship had an exponential tendency in Chevalier, Marathon and Waltham 29 in 2015 and tended towards an asymptotic maximum in Marathon in 2016 (Figure 3). The shoots of plants grown in 2015 had greater shoot Zn concentrations than those grown in 2016, which had greater shoot $\mathrm{Zn}$ concentrations than those grown in 2017 when grown in the same substrates (Table S1, Figure 3). Genotypes differed in their relationship between shoot $\mathrm{Zn}$ concentration and substrate $\mathrm{Zn}$ concentration (Figure 3). In general, the shoot $\mathrm{Zn}$ concentration in Belstar increased the least and the shoot Zn concentration in Waltham 29 the most, with increasing substrate Zn concentration across the three years of the study (Figure 3). 
Table 1. Maximum shoot biomass and critical substrate zinc $(\mathrm{Zn})$ and shoot $\mathrm{Zn}$ concentrations at which shoot dry biomass was reduced below 90\%, estimated from the relationships shown in Figures 1 and 2 derived from the data expressed on a dry weight (DW) basis presented in Supplementary Table S1.

\begin{tabular}{|c|c|c|c|c|c|}
\hline \multirow[b]{2}{*}{ Year } & \multirow[b]{2}{*}{ Genotypes } & \multicolumn{2}{|c|}{ Maximum Shoot Biomass } & \multicolumn{2}{|c|}{ Critical Zn Concentration } \\
\hline & & $\begin{array}{c}\text { Substrate Zn } \\
\text { Regression (g DW) }\end{array}$ & $\begin{array}{c}\text { Shoot Zn } \\
\text { Regression (g DW) }\end{array}$ & Substrate $\left(\mathrm{mg} \mathrm{L}^{-1}\right)$ & Shoot (mg g $\left.{ }^{-1} \mathrm{DW}\right)$ \\
\hline \multicolumn{6}{|c|}{ Cabbage } \\
\hline 2014 & Bison & 1.07 & 1.06 & 96 & 0.789 \\
\hline 2014 & Cape Horn & 2.08 & 2.06 & 100 & 0.802 \\
\hline 2014 & Tundra & 1.52 & 1.52 & 260 & 1.201 \\
\hline 2014 & Red Drumhead & 1.48 & 1.45 & 5 & 0.074 \\
\hline \multicolumn{6}{|c|}{ Broccoli } \\
\hline 2015 & Belstar & 11.33 & 11.33 & 107 & 0.434 \\
\hline 2015 & Chevalier & 10.72 & 10.72 & 105 & 0.499 \\
\hline 2015 & Marathon & 11.87 & 11.87 & 121 & 0.514 \\
\hline 2015 & Waltham 29 & 9.40 & 9.64 & 121 & 0.117 \\
\hline 2016 & Belstar & 3.12 & 3.12 & 139 & 1.018 \\
\hline 2016 & Chevalier & 3.68 & 3.68 & 120 & 0.901 \\
\hline 2016 & Marathon & 3.54 & 3.55 & 43 & 0.277 \\
\hline 2016 & Waltham 29 & 2.91 & 2.91 & 68 & 0.406 \\
\hline 2017 & Belstar & 5.51 & 5.51 & 408 & 1.666 \\
\hline 2017 & Chevalier & 7.03 & 7.03 & 308 & $1 . .424$ \\
\hline 2017 & Marathon & 6.68 & 6.70 & 332 & 1.527 \\
\hline 2017 & Waltham 29 & 6.18 & 6.24 & 271 & 1.195 \\
\hline
\end{tabular}

Table 2. Gradients and intercepts for linear regressions between shoot zinc ( $\mathrm{Zn})$ concentrations and substrate $\mathrm{Zn}$ concentrations of four cabbage genotypes studied in 2014 and four broccoli genotypes studied in 2015, 2016 and 2017.

\begin{tabular}{|c|c|c|c|c|}
\hline \multirow{2}{*}{ Year } & \multicolumn{4}{|c|}{ Gradient (mg Zn kg ${ }^{-1} \mathrm{DW} / \mathrm{mg} \mathrm{Zn} \mathrm{L}^{-1}$ ), Intercept (mg Zn kg ${ }^{-1} \mathrm{DW}$} \\
\hline & Bison & Cape Horn & Tundra & Red Drumhead \\
\hline \multirow[t]{2}{*}{2014} & $\begin{array}{l}5.802, \\
73.64\end{array}$ & $5.209,85.92(\mathrm{~A})$ & $4.620,4.706$ & $5.641,83.76(\mathrm{~A})$ \\
\hline & Belstar & Chevalier & Marathon & Waltham 29 \\
\hline 2015 & $\begin{array}{l}7.126 \\
70.16\end{array}$ & $5.170,5.644(\mathrm{E})$ & $5.015,12.83(\mathrm{E})$ & $6.853,36.36(\mathrm{E})$ \\
\hline 2016 & $\begin{array}{l}5.654 \\
74.84\end{array}$ & $5.714,80.16$ & $5.894,88.42$ & $6.350,12.32$ \\
\hline 2017 & $\begin{array}{l}3.997 \\
49.46\end{array}$ & $4.837,8.768$ & $4.680,7.523$ & $4.452,11.53$ \\
\hline
\end{tabular}

Data are regressions based on six substrate Zn concentrations, except for the cabbage genotypes Cape Horn and Red Drumhead in 2014 and the broccoli genotypes Chevalier, Marathon and Waltham 29 in 2015, which are regressions based on five substrate $\mathrm{Zn}$ concentrations $\leq 300 \mathrm{mg} \mathrm{Zn} \mathrm{L}^{-1}$. (A) Asymptotic, and (E) exponential regressions shown in Figures 1 and 3.

Shoot DW decreased with increasing shoot Zn concentration in all years in all genotypes (Figure 4). However, the estimated critical shoot Zn concentration for shoot DW accumulation differed between years and, apparently, among genotypes (Table 1). In general, shoot DW of Belstar appeared less sensitive to shoot Zn concentration than the other cultivars, particularly in 2016 and 2017, whilst Waltham 29 was among the most sensitive genotypes to shoot Zn concentration (Table 1). In 2015, the critical shoot Zn concentrations ranged between $0.117 \mathrm{mg} \mathrm{g}^{-1} \mathrm{DW}$ for Waltham 29 and $0.514 \mathrm{mg} \mathrm{g}^{-1} \mathrm{DW}$ for Marathon. In 2016, the critical shoot $\mathrm{Zn}$ concentrations ranged between $0.277 \mathrm{mg} \mathrm{g}^{-1} \mathrm{DW}$ for Marathon and $1.018 \mathrm{mg} \mathrm{g}^{-1} \mathrm{DW}$ for Belstar. In 2017, the critical shoot Zn concentrations ranged between $1.195 \mathrm{mg} \mathrm{g}^{-1} \mathrm{DW}$ for Waltham 29 and $1.666 \mathrm{mg} \mathrm{g}^{-1} \mathrm{DW}$ for Belstar. 

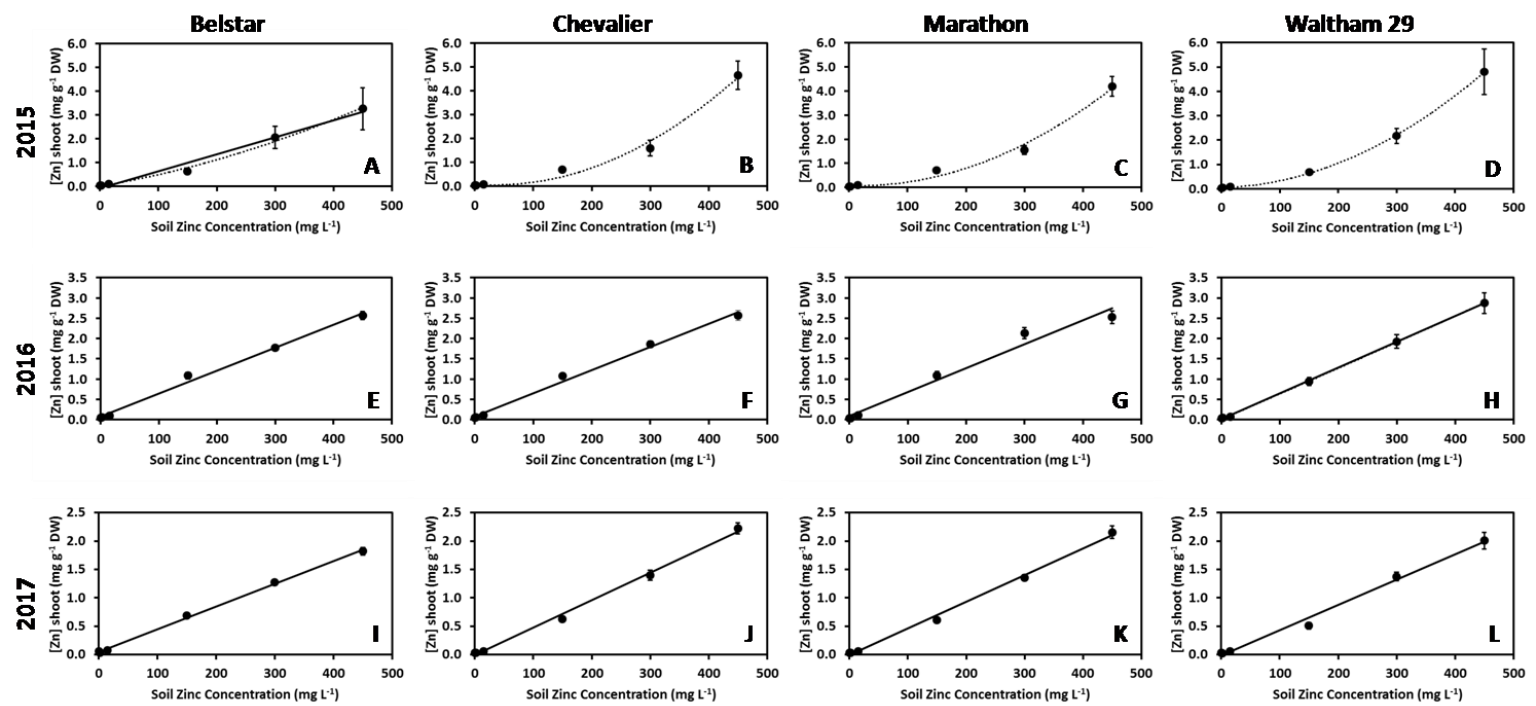

Figure 3. Relationship between substrate zinc (Zn) concentration and shoot $\mathrm{Zn}$ concentration of (A,E,I) Belstar, (B,F,J) Chevalier, (C,G,K) Marathon and (D,H,L) Waltham 29 broccoli genotypes grown in 2015 (top row), 2016 (middle row) and 2017 (bottom row). Parameters for linear regression lines are given in Table 2. Data are shown as the mean and standard error of the mean (Table S1).
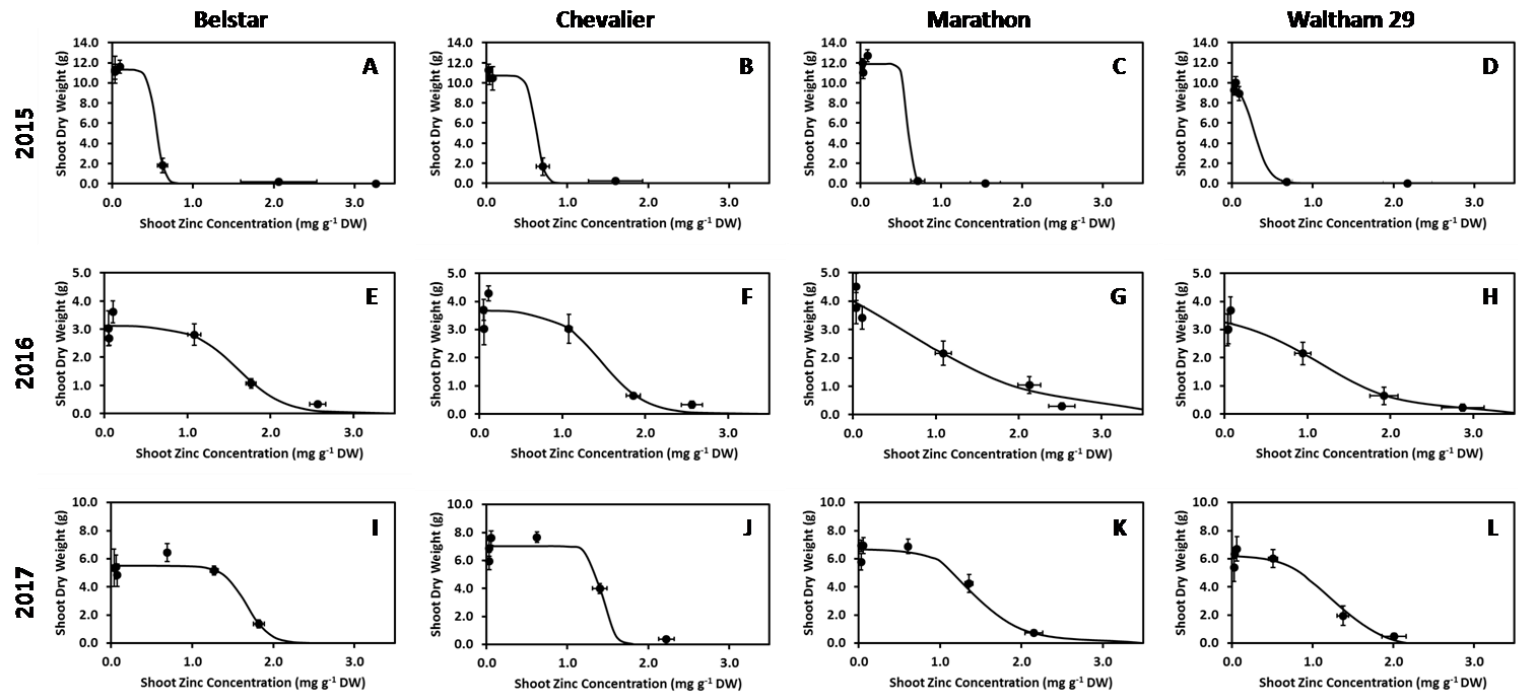

Figure 4. Relationship between shoot zinc concentration (Zn) and shoot dry weight (DW) of (A,E,I) Belstar, (B,F,J) Chevalier, (C,G,K) Marathon and (D,H,L) Waltham 29 broccoli genotypes grown in 2015 (top row), 2016 (middle row) and 2017 (bottom row). Regression lines are fitted to the equation $\mathrm{DW}=\mathrm{a} /\left(1+\operatorname{EXP}\left(\mathrm{b}^{*}((\mathrm{Zn})-\mathrm{c})\right)\right)+\mathrm{d}$, where the minimum biomass equals $\mathrm{d}$, the maximum biomass equals $\mathrm{a}+\mathrm{d}, \mathrm{c}$ is the substrate $\mathrm{Zn}$ concentration at the point of inflection and the slope of the relationship at the point of inflection is given by $-a b / 4$. For all lines $d=0$ and $a$ is the maximum shoot biomass. Parameters a, b and c were: $(A) a=11.3, b=20.3, c=0.542$ for Belstar in 2015, (B) a = 10.7, b = 19.5, $c=0.612$ for Chevalier in 2015, (C) $a=11.9, b=30.8, c=0.585$ for Marathon in 2015, (D) $a=10.4$, $\mathrm{b}=10.5, \mathrm{c}=0.272$ for Waltham 29 in 2015, (E) a = 3.13, b=3.63, c = 1.61 for Belstar in 2016, (F) a = 3.69, $\mathrm{b}=3.75, \mathrm{c}=1.47$ for Chevalier in 2016, (G) a = 5.97, b = 1.19, c = 0.596 for Marathon in 2016, (H) a = 3.64, $\mathrm{b}=1.89, \mathrm{c}=1.14$ for Waltham 29 in 2016, (I) a = 5.51, b = 7.17, c = 1.66 for Belstar in 2017, (J) a = 7.02, $\mathrm{b}=13.1, \mathrm{c}=1.42$ for Chevalier in 2017, $(\mathbf{K}) \mathrm{a}=6.70, \mathrm{~b}=3.66, \mathrm{c}=1.53$ for Marathon in 2017, $(\mathbf{L}) \mathrm{a}=6.24$, $\mathrm{b}=4.05, \mathrm{c}=1.20$ for Waltham 29 in 2017. Data are shown as the mean and standard error of the mean (Table S1). 
There was no relationship between shoot DW of broccoli genotypes and either the critical substrate $\mathrm{Zn}$ concentration or the critical shoot $\mathrm{Zn}$ concentration (data not shown). However, although estimates of both the critical substrate $\mathrm{Zn}$ concentration and the critical shoot $\mathrm{Zn}$ concentration differed among experiments (Table 1), there was a linear relationship between the critical shoot $\mathrm{Zn}$ concentration and the critical substrate $\mathrm{Zn}$ concentration both among genotypes in 2016 and 2017 and among experiments performed in different years (Figure 5A). Data for cabbage genotypes obtained in 2014 also exhibited a similar relationship (Figure 5A). Thus, plants that are better able to tolerate the accumulation of $\mathrm{Zn}$ in their shoots can survive and grow in substrates with larger substrate $\mathrm{Zn}$ concentrations. There was also a negative relationship between the critical substrate $\mathrm{Zn}$ concentration and the initial linear rate of change of Zn uptake with increasing substrate Zn concentration in broccoli (Figure 5B), which might be explained because greater shoot $\mathrm{Zn}$ accumulation at any given substrate $\mathrm{Zn}$ concentration will result in a lower critical substrate $\mathrm{Zn}$ concentration should all other factors remain constant. However, there was also a negative relationship between the critical shoot $\mathrm{Zn}$ concentration and the initial linear rate of change of $\mathrm{Zn}$ uptake with increasing substrate $\mathrm{Zn}$ concentration in broccoli (Figure 5C). This observation might suggest that tolerance to increasing shoot $\mathrm{Zn}$ concentration is promoted by (unknown) substrate factors that change with increasing substrate $\mathrm{Zn}$ concentrations. Similar negative relationships between both the critical substrate and shoot $\mathrm{Zn}$ concentrations and the initial linear rate of change of $\mathrm{Zn}$ uptake with increasing substrate $\mathrm{Zn}$ concentration were also observed in cabbage (Figure 5B,C).
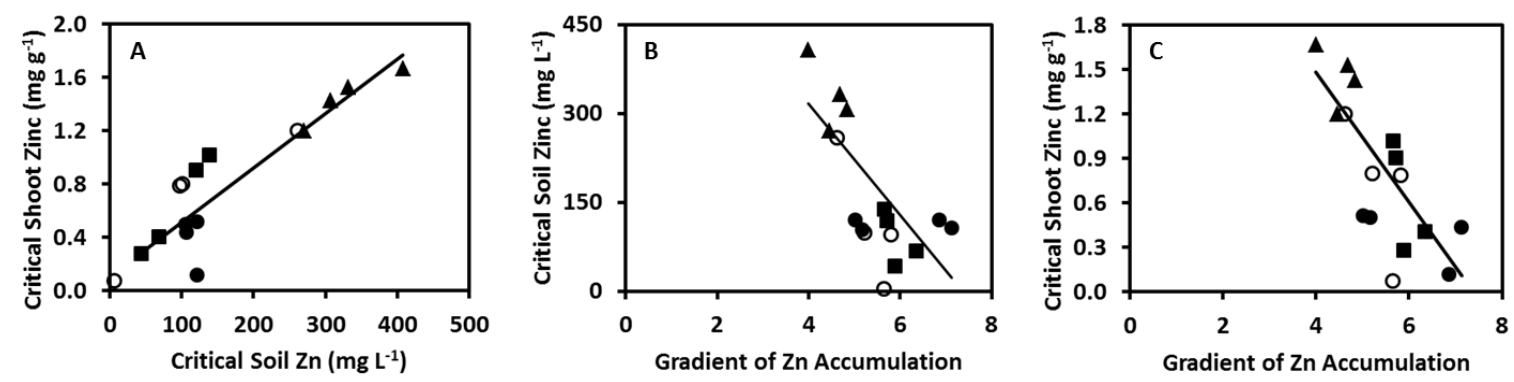

Figure 5. Relationship between (A) critical shoot zinc (Zn) concentrations and critical substrate $\mathrm{Zn}$ concentrations, (B) critical substrate $\mathrm{Zn}$ concentrations and the linear rates of change of $\mathrm{Zn}$ uptake with increasing substrate $\mathrm{Zn}$ concentration and $(\mathrm{C})$ critical shoot $\mathrm{Zn}$ concentrations and the linear rate of change of $\mathrm{Zn}$ uptake with increasing substrate $\mathrm{Zn}$ concentration among four genotypes of broccoli studied in 2015 (closed circles), 2016 (squares) and 2017 (triangles), and four genotypes of cabbage studied in 2014 (open circles). The regression line in panels A $\left(y=4.09 x+101 \mathrm{mg} \mathrm{kg}-1 / \mathrm{mg} \mathrm{L}^{-1}\right.$, $\left.R^{2}=0.840, n=12\right)$ and $\mathrm{B}\left(y=-0.438 x+3.232, R^{2}=0.640, n=12\right)$ and $\mathrm{C}\left(y=-93.96 x+693.2, R^{2}=0.585\right.$, $n=12$ ) are for broccoli only. Data are presented in Tables 1 and 2.

\section{Discussion}

Increasing the substrate $\mathrm{Zn}$ concentration above a critical value reduced the shoot DW of all cabbage and broccoli genotypes studied (Table S1, Figures 1 and 2). The critical substrate fertiliser $\mathrm{Zn}$ concentration, which is less than the total available $\mathrm{Zn}$ in the substrate but approximates the $\mathrm{Zn}$ readily available to the plant in the substrate, varied between years and differed among the genotypes, ranging from 5 to $260 \mathrm{mg} \mathrm{Zn} \mathrm{L}^{-1}$ among cabbage genotypes studied in 2014 and between 43 and $408 \mathrm{mg} \mathrm{Zn} \mathrm{L}^{-1}$ for the broccoli genotypes studied in 2015-2017 (Table 1). These values are much lower than statutory maximum annual $\mathrm{Zn}$ loading rates to soils in Europe and elsewhere [37].

The phytoavailability of soil $\mathrm{Zn}$ is affected by many factors [38]. These are often soil-specific. A major determinant of $\mathrm{Zn}$ phytoavailability in soils is $\mathrm{pH}$ but soil organic matter content, mineral and clay composition, porosity and moisture content are also influential. In addition, although brassicas are non-mycorrhizal, interactions with soil biota can also affect $\mathrm{Zn}$ phytoavailability in soils. It is, therefore, unwise to extrapolate from the critical substrate fertiliser $\mathrm{Zn}$ concentrations obtained in the 
experiments reported here (Table 1) directly to farmers' fields. It is also noteworthy that in soils where the phytoavailability of $\mathrm{Zn}$ applied as fertiliser decreases rapidly, the $\mathrm{Zn}$ biofortification of crops is generally achieved by foliar application of $Z n$ fertilisers $[1,5,9,11,13,15,20,37]$.

A variety of relationships between substrate $\mathrm{Zn}$ concentration and shoot $\mathrm{Zn}$ concentration were observed (Figures 1 and 3). A linear relationship between substrate $\mathrm{Zn}$ concentration and shoot $\mathrm{Zn}$ concentration was often observed but an asymptotic relationship toward a maximum shoot $\mathrm{Zn}$ concentration was observed for cabbage genotypes Cape Horn and Red Drumhead in 2014 and an exponential relationship was observed for broccoli genotypes Chevalier, Marathon and Waltham 29 in 2015. Previous studies of cabbage suggest a linear relationship between soil $\mathrm{Zn}$ concentration and shoot $\mathrm{Zn}$ concentration $[39,40]$. It is possible that the asymptotic relationship towards a maximum shoot $\mathrm{Zn}$ concentration was a consequence of measuring shoot $\mathrm{Zn}$ concentrations of only plants that survived the presence of a given substrate $\mathrm{Zn}$ concentration, which might have restricted $\mathrm{Zn}$ accumulation.

Differences in the gradients of the relationship between substrate $\mathrm{Zn}$ concentration and shoot $\mathrm{Zn}$ concentration were observed among both cabbage and broccoli genotypes (Table 1). Among the cabbage genotypes, shoot $\mathrm{Zn}$ concentrations were greatest in Bison and least in Tundra (Table S1, Figure 1), which is consistent with the observations of Broadley et al. [28] when ample phosphorus was supplied. Among the broccoli genotypes, Waltham 29 generally had the greatest shoot $\mathrm{Zn}$ concentration and Belstar the smallest shoot $\mathrm{Zn}$ concentration when $\mathrm{Zn}$ fertiliser was applied, although this order was reversed when no $\mathrm{Zn}$ fertiliser was applied (Table S1, Figure 3). These data reinforce previous studies reporting significant differences in shoot $Z n$ concentrations among both cabbage $[26,29]$ and broccoli genotypes $[30,31]$. Shoot $\mathrm{Zn}$ concentrations determined at the same substrate $\mathrm{Zn}$ concentration differed between years for all broccoli genotypes (Table S1, Figure 3). A similar observation was made by [27], who reported that there were significant differences in the shoot $\mathrm{Zn}$ concentrations of kale and collard genotypes grown in different years in the field. The differences reported here might be related to the season in which the plants were grown and, therefore, the glasshouse temperature, incident photosynthetically active radiation, day length or another uncontrolled environmental factor. However, no obvious relationships between accumulated temperature $\left({ }^{\circ} \mathrm{C}\right.$ day) or solar radiation were observed for the relationships between substrate $\mathrm{Zn}$ concentration, shoot $\mathrm{Zn}$ concentration and shoot DW.

Critical shoot Zn concentrations ranged from 0.074 to $1.201 \mathrm{mg} \mathrm{Zn} \mathrm{g}^{-1} \mathrm{DW}$ among the cabbage genotypes studied in 2014 and between 0.117 and $1.666 \mathrm{mg} \mathrm{Zn} \mathrm{g}^{-1} \mathrm{DW}$ among the broccoli genotypes studied in 2015-2017 (Table 1). The smallest values are within the range (0.1-0.3 $\left.\mathrm{mg} \mathrm{Zn} \mathrm{g}^{-1} \mathrm{DW}\right)$ that is commonly quoted for critical shoot $\mathrm{Zn}$ concentrations of plants $[35,41]$ and the largest values exceed current estimates of the $\mathrm{Zn}$ biofortification potential of leafy vegetables ( $0.7 \mathrm{mg} \mathrm{Zn} \mathrm{g}^{-1} \mathrm{DW}$; [13]). The cabbage genotypes studied appeared to have very different critical shoot $\mathrm{Zn}$ concentrations, ranging from $0.074 \mathrm{mg} \mathrm{Zn} \mathrm{g}^{-1} \mathrm{DW}$ for Red Drumhead to $1.201 \mathrm{mg} \mathrm{Zn} \mathrm{g}^{-1} \mathrm{DW}$ for Tundra (Table 1; Figure 1). These data are consistent with previous studies indicating that the critical shoot $\mathrm{Zn}$ concentration of cabbage approximates $0.05-0.40 \mathrm{mg} \mathrm{Zn} \mathrm{g}^{-1} \mathrm{DW}[35,40,42,43]$ and that cabbage genotypes differ in their critical shoot $\mathrm{Zn}$ concentration [44]. Differences in critical shoot $\mathrm{Zn}$ concentration appeared to be less pronounced among the broccoli genotypes studied, although Waltham 29 appeared more sensitive and Belstar less sensitive than the other genotypes to increasing shoot Zn concentration (Table 1; Figure 4). Estimates of critical shoot $\mathrm{Zn}$ concentrations for broccoli genotypes differed between years (Table 1, Figure 4). This might be attributed to differences in the growth environment in different years. Variation in critical shoot $\mathrm{Zn}$ concentration is observed among studies of other brassicaceous species, such as Brassica napus L. (compare [45-49]) and Brassica juncea (L.) Czern [50-52] that might be related to either the genotypes studied or the experimental conditions.

\section{Conclusions}

Recent efforts to biofortify edible crops with Zn have focused primarily on staple crops, such as cereals, pulses, cassava and potatoes, and maximum $\mathrm{Zn}$ concentrations of $0.02-0.10 \mathrm{mg} \mathrm{g}^{-1} \mathrm{DW}$, 
depending upon the crop, have been achieved without loss of yield [1,6,9,12-21]. The critical shoot Zn concentrations in cabbage and broccoli reported here generally exceed these values (Table 1). This supports the general hypothesis that greater $\mathrm{Zn}$ concentrations can be achieved in leafy vegetables than in seeds, roots or tubers [13]. Furthermore, since leafy brassicas, unlike the seeds of legumes and cereals, do not contain large concentrations of phytic acid, the $\mathrm{Zn}$ in cabbage and broccoli should be readily bioavailable to humans [8]. This observation could have implications for increasing dietary $\mathrm{Zn}$ intake and the alleviation of $\mathrm{Zn}$ deficiencies in human populations. If it is assumed that brassicas constitute $5 \%$ of the $\mathrm{Zn}$ in current diets [3,4], increasing their shoot $\mathrm{Zn}$ concentrations from $0.057 \mathrm{mg} \mathrm{Zn} \mathrm{g}^{-1} \mathrm{DW}$-the average value obtained without the addition of $\mathrm{Zn}$ fertilisers in the six experiments reported here (Table S1) - to $0.10-0.30 \mathrm{mg} \mathrm{Zn} \mathrm{g}^{-1} \mathrm{DW}$ through the application of $\mathrm{Zn}$ fertilisers to appropriate genotypes could increase dietary $\mathrm{Zn}$ intake by $3.8-21.3 \%$ without loss of crop yield. This has the potential to raise the $\mathrm{Zn}$ status and general health of human populations without any necessity for people to change their diets. However, there might be socioeconomic constraints to developing a strategy to alleviate $\mathrm{Zn}$ deficiencies in human populations through $\mathrm{Zn}$ biofortification of leafy vegetables because (1) the application of $\mathrm{Zn}$ fertilisers for $\mathrm{Zn}$ biofortification is an additional production cost and (2) appropriate infrastructure is required to distribute $\mathrm{Zn}$ fertilisers to produce $\mathrm{Zn}$ biofortified crops and to distribute $\mathrm{Zn}$ biofortified crops to populations that lack sufficient $\mathrm{Zn}$ in their diets [1].

Supplementary Materials: The following are available online at http:/ / www.mdpi.com/2077-0472/8/3/32/s1, Table S1: The number of replicate plants surviving and the mean fresh weight (FW), dry weight (DW) and zinc (Zn) concentrations of the shoots of five cabbage (Brassica oleracea L. var. capitata) genotypes (Bison, Cape Horn, Elisa, Red Drumhead and Tundra) grown in 2012, 2013 and 2014 in a standard substrate into which no $\mathrm{Zn}, 0.075 \mathrm{mg} \mathrm{Zn} \mathrm{L}^{-1}$ substrate, $0.15 \mathrm{mg} \mathrm{Zn} \mathrm{L}^{-1}$ substrate, $1.5 \mathrm{mg} \mathrm{Zn} \mathrm{L}^{-1}$ substrate, $15 \mathrm{mg} \mathrm{Zn} \mathrm{L}^{-1}$ substrate, $150 \mathrm{mg} \mathrm{Zn} \mathrm{L}^{-1}$ substrate, $300 \mathrm{mg} \mathrm{Zn} \mathrm{L}{ }^{-1}$ substrate or $450 \mathrm{mg} \mathrm{Zn} \mathrm{L}{ }^{-1}$ substrate, $500 \mathrm{mg} \mathrm{Zn} \mathrm{L}^{-1}$ substrate, $1000 \mathrm{mg} \mathrm{Zn} \mathrm{L}^{-1}$ substrate, $1500 \mathrm{mg} \mathrm{Zn} \mathrm{L}^{-1}$ substrate or $3000 \mathrm{mg} \mathrm{Zn} \mathrm{L}{ }^{-1}$ substrate was incorporated depending on the year of the study, and four broccoli (Brassica oleracea L. var. italica) genotypes (Belstar, Chevalier, Marathon and Waltham 29) grown in 2015, 2016 and 2017 in a standard substrate into which no Zn, $1.5 \mathrm{mg} \mathrm{Zn} \mathrm{L}^{-1}$ substrate, $15 \mathrm{mg} \mathrm{Zn} \mathrm{L}^{-1}$ substrate, $150 \mathrm{mg} \mathrm{Zn} \mathrm{L}^{-1}$ substrate, $300 \mathrm{mg} \mathrm{Zn} \mathrm{L}^{-1}$ substrate or $450 \mathrm{mg} \mathrm{Zn} \mathrm{L}^{-1}$ substrate was incorporated. Data for FW, $\mathrm{DW}$ and shoot $\mathrm{Zn}$ concentrations are expressed as the mean \pm standard error of the mean (SE) for $n$ surviving replicate plants.

Acknowledgments: This work was supported by the Rural and Environment Science and Analytical Services (RESAS) Division of the Scottish Government, by an EU Marie Curie Intra-European Fellowship (Grant \#623305) to Paula Pongrac, and by a Rank Prize Funds Vacation Studentship to Claire Sneddon.

Author Contributions: All authors conceived and designed the experiments; C.C.S., J.A.T. and G.W. performed the experiments; C.C.S. and P.J.W. analysed the data; P.J.W. drafted the manuscript; all authors commented on the work.

Conflicts of Interest: The authors declare no conflicts of interest.

\section{References}

1. White, P.J.; Broadley, M.R. Biofortification of crops with seven mineral elements often lacking in human diets-Iron, zinc, copper, calcium, magnesium, selenium and iodine. New Phytol. 2009, 182, 49-84. [CrossRef] [PubMed]

2. Wessells, K.R.; Singh, G.M.; Brown, K.H. Estimating the global prevalence of inadequate zinc intake from national food balance sheets: Effects of methodological assumptions. PLoS ONE 2012, 7, e50565. [CrossRef] [PubMed]

3. Kumssa, D.B.; Joy, E.J.M.; Ander, E.L.; Watts, M.J.; Young, S.D.; Walker, S.; Broadley, M.R. Dietary calcium and zinc deficiency risks are decreasing but remain prevalent. Sci. Rep. 2015, 5, 10974. [CrossRef] [PubMed]

4. White, P.J. Biofortification of edible crops. In eLS; John Wiley \& Sons: Chichester, UK, 2016. [CrossRef]

5. Cakmak, I.; McLaughlin, M.J.; White, P. Zinc for better crop production and human health. Plant Soil 2017, 411, 1-4. [CrossRef]

6. Cakmak, I. Enrichment of cereal grains with zinc: Agronomic or genetic biofortification? Plant Soil 2008, 302, 1-17. [CrossRef] 
7. Khoshgoftarmanesh, A.H.; Schulin, R.; Chaney, R.L.; Daneshbakhsh, B.; Afyuni, M. Micronutrient-efficient genotypes for crop yield and nutritional quality in sustainable agriculture. A review. Agron. Sustain. Dev. 2010, 30, 83-107. [CrossRef]

8. Joy, E.J.M.; Ander, E.L.; Young, S.D.; Black, C.R.; Watts, M.J.; Chilimba, A.D.C.; Chilimba, B.; Siyame, E.W.P.; Kalimbira, A.A.; Hurst, R.; et al. Dietary mineral supplies in Africa. Physiol. Plant. 2014, 151, $208-229$. [CrossRef] [PubMed]

9. Velu, G.; Ortiz-Monasterio, I.; Cakmak, I.; Hao, Y.; Singh, R.P. Biofortification strategies to increase grain zinc and iron concentrations in wheat. J. Cereal Sci. 2014, 59, 365-372. [CrossRef]

10. Gartler, J.; Robinson, B.; Burton, K.; Clucas, L. Carbonaceous soil amendments to biofortify crop plants with zinc. Sci. Total Environ. 2013, 465, 308-313. [CrossRef] [PubMed]

11. Šlosár, M.; Mezeyová, I.; Hegedüsová, A.; Andrejiová, A.; Kováčik, P.; Lošák, T.; Kopta, T.; Keutgen, A.J. Effect of zinc fertilisation on yield and selected qualitative parameters of broccoli. Plant Soil Environ. 2017, 63, 282-287. [CrossRef]

12. Pfeiffer, W.H.; McClafferty, B. HarvestPlus: Breeding crops for better nutrition. Crop Sci. 2007, 47, S88-S105. [CrossRef]

13. White, P.J.; Broadley, M.R. Physiological limits to zinc biofortification of edible crops. Front. Plant Sci. 2011, 2, 80. [CrossRef] [PubMed]

14. Sayre, R.; Beeching, J.R.; Cahoon, E.B.; Egesi, C.; Fauquet, C.; Fellman, J.; Fregene, M.; Gruissem, W.; Mallowa, S.; Manary, M.; et al. The BioCassava Plus Program: Biofortification of cassava for Sub-Saharan Africa. Ann. Rev. Plant Biol. 2011, 62, 251-272. [CrossRef] [PubMed]

15. Phattarakul, N.; Rerkasem, B.; Li, L.J.; Wu, L.H.; Zou, C.Q.; Ram, H.; Sohu, V.S.; Kang, B.S.; Surek, H.; Kalayci, M.; et al. Biofortification of rice grain with zinc through zinc fertilization in different countries. Plant Soil 2012, 361, 131-141. [CrossRef]

16. Zou, C.Q.; Zhang, Y.Q.; Rashid, A.; Ram, H.; Savasli, E.; Arisoy, R.Z.; Ortiz-Monasterio, I.; Simunji, S.; Wang, Z.H.; Sohu, V.; et al. Biofortification of wheat with zinc through zinc fertilization in seven countries. Plant Soil 2012, 361, 119-130. [CrossRef]

17. Saltzman, A.; Birol, E.; Bouis, H.E.; Boy, E.; De Moura, F.F.; Islam, Y.; Pfeiffer, W.H. Biofortification: Progress toward a more nourishing future. Glob. Food Secur. 2013, 2, 9-17. [CrossRef]

18. Pucher, A.; Høgh-Jensen, H.; Gondah, J.; Hash, C.T.; Haussmann, B.I.G. Micronutrient density and stability in West African pearl millet-Potential for biofortification. Crop Sci. 2014, 54, 1709-1720. [CrossRef]

19. Mallikarjuna, M.G.; Thirunavukkarasu, N.; Hossain, F.; Bhat, J.S.; Jha, S.K.; Rathore, A.; Agrawal, P.K.; Pattanayak, A.; Reddy, S.S.; Gularia, S.K.; et al. Stability performance of inductively coupled plasma mass spectrometry-phenotyped kernel minerals concentration and grain yield in maize in different agro-climatic zones. PLoS ONE 2015, 10, e0139067. [CrossRef]

20. Chen, X.-P.; Zhang, Y.-Q.; Tong, Y.-P.; Xue, Y.-F.; Liu, D.Y.; Zhang, W.; Deng, Y.; Meng, Q.-F.; Yue, S.-C.; Yan, P.; et al. Harvesting more grain zinc of wheat for human health. Sci. Rep. 2017, 7, 7016. [CrossRef] [PubMed]

21. White, P.J.; Thompson, J.A.; Wright, G.; Rasmussen, S.K. Biofortifying Scottish potatoes with zinc. Plant Soil 2017, 411, 151-165. [CrossRef]

22. Thomson, C.A.; Newton, T.R.; Graver, E.J.; Jackson, K.A.; Reid, P.M.; Hartz, V.L.; Cussler, E.C.; Hakim, I.A. Cruciferous vegetable intake questionnaire improves cruciferous vegetable intake estimates. J. Am. Diet. Assoc. 2007, 107, 631-641. [CrossRef] [PubMed]

23. Food and Agriculture Organization of the United Nations FAOSTAT. Available online: http:/ /www.fao.org/ faostat/en/\#home (accessed on 25 October 2017).

24. Moreno, D.A.; Carvajal, M.; López-Berenguer, C.; Garcia-Viguera, C. Chemical and biological characterization of nutraceutical compounds of broccoli. J. Pharm. Biomed. Anal. 2006, 41, 1508-1522. [CrossRef] [PubMed]

25. Verkerk, R.; Schreiner, M.; Krumbein, A.; Ciska, E.; Holst, B.; Rowland, I.; De Schrijver, R.; Hansen, M.; Gerhauser, C.; Mithen, R.; et al. Glucosinolates in Brassica vegetables: The influence of the food supply chain on intake, bioavailability and human health. Mol. Nutr. Food Res. 2009, 53, S219. [CrossRef] [PubMed]

26. Harrison, H.C.; Bergman, E.L. Calcium, magnesium, and potassium interrelationships affecting cabbage production. J. Am. Soc. Hortic. Sci. 1981, 106, 500-503.

27. Kopsell, D.E.; Kopsell, D.A.; Lefsrud, M.G.; Curran-Celentano, J. Variability in elemental accumulations among leafy Brassica oleracea cultivars and selections. J. Plant Nutr. 2004, 27, 1813-1826. [CrossRef] 
28. Broadley, M.R.; Lochlainn, S.; Hammond, J.P.; Bowen, H.C.; Cakmak, I.; Eker, S.; Erdem, H.; King, G.J.; White, P.J. Shoot zinc (Zn) concentration varies widely within Brassica oleracea $\mathrm{L}$. and is affected by soil $\mathrm{Zn}$ and phosphorus (P) levels. J. Hortic. Sci. Biotechnol. 2010, 85, 375-380. [CrossRef]

29. Singh, B.K.; Sharma, S.R.; Singh, B. Variation in mineral concentrations among cultivars and germplasms of cabbage. J. Plant Nutr. 2010, 33, 95-104. [CrossRef]

30. Kałużewicz, A.; Bosiacki, M.; Frąszczak, B. Mineral composition and the content of phenolic compounds of ten broccoli cultivars. J. Elementol. 2016, 21, 53-65. [CrossRef]

31. Šindelářová, K.; Száková, J.; Tremlová, J.; Mestek, O.; Praus, L.; Kaňa, A.; Najmanová, J.; Tlustoš, P. The response of broccoli (Brassica oleracea convar. italica) varieties on foliar application of selenium: Uptake, translocation, and speciation. Food Addit. Contam. A 2015, 32, 2027-2038. [CrossRef]

32. Xiao, Z.L.; Codling, E.E.; Luo, Y.G.; Nou, X.W.; Lester, G.E.; Wang, Q. Microgreens of Brassicaceae: Mineral composition and content of 30 varieties. J. Food Comp. Anal. 2016, 49, 87-93. [CrossRef]

33. Lewu, F.B.; Lewu, M.N.; Mavengahama, S. Influence of genotype and harvesting age on the mineral dynamics of Brassica oleracea var. acephala cultivated in South Africa. J. Food Agric. Environ. 2012, 10, 563-566.

34. Singh, B.K.; Sharma, S.R.; Singh, B. Genetic combining ability for concentration of mineral elements in cabbage head (Brassica oleracea var. capitata L.). Euphytica 2012, 184, 265-273. [CrossRef]

35. MacNicol, R.D.; Beckett, P.H.T. Critical tissue concentrations of potentially toxic elements. Plant Soil 1985, 85, 107-109. [CrossRef]

36. White, P.J.; Broadley, M.R.; Thompson, J.A.; McNicol, J.W.; Crawley, M.J.; Poulton, P.R.; Johnston, A.E. Testing the distinctness of shoot ionomes of angiosperm families using the Rothamsted Park Grass Continuous Hay Experiment. New Phytol. 2012, 196, 101-109. [CrossRef] [PubMed]

37. White, P.J.; Broadley, M.R.; Gregory, P.J. Managing the nutrition of plants and people. Appl. Environ. Soil Sci. 2012, 2012, 104826. [CrossRef]

38. Broadley, M.R.; White, P.J.; Hammond, J.P.; Zelko, I.; Lux, A. Zinc in plants. New Phytol. 2007, 173, 677-702. [CrossRef] [PubMed]

39. Xian, X. Effect of chemical forms of cadmium, zinc, and lead in polluted soils on their uptake by cabbage plants. Plant Soil 1989, 113, 257-264. [CrossRef]

40. Handreck, K.A. Total and extractable copper and zinc as assessors of phytotoxicity in soilless potting media. Commun. Soil Sci. Plant Anal. 1994, 25, 2313-2340. [CrossRef]

41. White, P.J.; Brown, P.H. Plant nutrition for sustainable development and global health. Ann. Bot. 2010, 105, 1073-1080. [CrossRef] [PubMed]

42. Barrameda-Medina, Y.; Montesinos-Pereira, D.; Romero, L.; Ruiz, J.M.; Blasco, B. Comparative study of the toxic effect of $\mathrm{Zn}$ in Lactuca sativa and Brassica oleracea plants: I. Growth, distribution, and accumulation of Zn, and metabolism of carboxylates. Environ. Exp. Bot. 2014, 107, 98-104. [CrossRef]

43. Paradisone, V.; Barrameda-Medina, Y.; Montesinos-Pereira, D.; Romero, L.; Esposito, S.; Ruiz, J.M. Roles of some nitrogenous compounds protectors in the resistance to zinc toxicity in Lactuca sativa cv. Phillipus and Brassica oleracea cv. Bronco. Acta Physiol. Plant. 2015, 37, 137. [CrossRef]

44. Kusznierewicz, B.; Baczek-Kwinta, R.; Bartoszek, A.; Piekarska, A.; Huk, A.; Manikowska, A.; Antonkiewicz, J.; Namiesnik, J.; Konieczka, P. The dose-dependent influence of zinc and cadmium contamination of soil on their uptake and glucosinolate content in white cabbage (Brassica oleracea var. capitata f. alba). Environ. Toxicol. Chem. 2012, 31, 2482-2489. [CrossRef] [PubMed]

45. Lu, Z.G.; Grewal, H.S.; Graham, R.D. Dry matter production and uptake of zinc and phosphorus in two oilseed rape genotypes under differential rates of zinc and phosphorus supply. J. Plant Nutr. 1998, 21, 25-38. [CrossRef]

46. Bernhard, R.; Verkleij, J.A.C.; Nelissen, H.J.M.; Vink, J.P.M. Plant-specific responses to zinc contamination in a semi-field lysimeter and on hydroponics. Environ. Pollut. 2005, 138, 100-108. [CrossRef] [PubMed]

47. Hernández-Allica, J.; Becerril, J.M.; Garbisu, C. Assessment of the phytoextraction potential of high biomass crop plants. Environ. Pollut. 2008, 152, 32-40. [CrossRef] [PubMed]

48. Wang, C.; Zhang, S.H.; Wang, P.F.; Hou, J.; Zhang, W.J.; Li, W.; Lin, Z.P. The effect of excess Zn on mineral nutrition and antioxidative response in rapeseed seedlings. Chemosphere 2009, 75, 1468-1476. [CrossRef] [PubMed]

49. Peško, M.; Molnárová, M.; Fargašová, A. Effect of lead and zinc treatments on Brassica napus L. (cv. Verona) plants: Accumulation and physio-biochemical changes. Fresenius Environ. Bull. 2015, 24, 3213-3219. 
50. Ebbs, S.D.; Kochian, L.V. Toxicity of zinc and copper to Brassica species: Implications for phytoremediation. J. Environ. Qual. 1997, 26, 776-781. [CrossRef]

51. Hamlin, R.L.; Schatz, C.; Barker, A.V. Zinc accumulation in Indian mustard as influenced by nitrogen and phosphorus nutrition. J. Plant Nutr. 2003, 26, 177-190. [CrossRef]

52. Hamlin, R.L.; Barker, A.V. Influence of ammonium and nitrate nutrition on plant growth and zinc accumulation by Indian mustard. J. Plant Nutr. 2006, 29, 1523-1541. [CrossRef] 